\title{
Effect of Environmentally Friendly Nutrition Supply on Stevia (Stevia rebaudiana B.) Production
}

\author{
Mária TAKÁCS-HÁJOS*, Tímea RUBÓCZKI, Fruzsina M. SZABÓ, \\ Annamária KISS
}

\author{
University of Debrecen, Faculty of Agricultural and Food Science and Environmental Management, Institute of Horticulture, 138 Böszörményi \\ Str., Debrecen, H-4032, Hungary; hajos@agr.unideb.hu ('correspondingauthor); ruboczkit@agr.unideb.hu; \\ fruzsina.m.szabo@gmail.com;dante147@gmail.com
}

\begin{abstract}
The experiment was carried out on raised bed ( 3 rows) with $33 \mathrm{~cm}$ row distance and $25 \mathrm{~cm}$ between the plants and 24 plant $\mathrm{m}^{-2}$ density. The plantation was prepared on 28 May, 2015 with about $10 \mathrm{~cm}$ high transplants. The soil surface was mulched with wooden chips $\left(5 \mathrm{~cm}\right.$ layer). The aim was to evaluate the environmentally friendly fertilizers (Dudarit $-150 \mathrm{~g} \mathrm{~m}^{-2}$, Sprintalga $-0.04 \%$ concentration four times $200 \mathrm{~mL}$ per plant). During the vegetation period pruning was applied at $30 \mathrm{~cm}$ plant height at the $4^{\text {th }}$ double leaf from the soil surface and two cuttings (13 Aug and 29 Sept). By evaluating the effect of treatment on the leaf surface and chlorophyll content, statistically significant results were not found. Higher SPAD (relative chlorophyll content) value was measured in the middle of the growing period compared to the end of the vegetation when the plants were older and the temperature started to decrease. The positive effect of Dudarit and Sprintalga was clear on the plant height and biomass production. The dried herb yield was higher $\left(4 \mathrm{~kg} \mathrm{~m}^{-2}\right)$ on treated plots comparing to control $\left(3 \mathrm{~kg} \mathrm{~m}^{-2}\right)$. Although increased photosynthetic intensity was not detected on treated plots, the plantation showed greater vitality and side shoot improvement to control plots. Under our circumstances, the environmentally friendly fertilization (Dudarit and Sprintalga) has increased the dried leaves yield with $20 \%$ by similar stevioside and rebaudioside-A content.
\end{abstract}

Keywords: fertilizer; leaf yield; rebaudioside-A; Stevia rebaudiana; stevioside

\section{Introduction}

Stevia provides a good alternative for the sweet taste in the diet of people with diabetes besides of protecting against obesity. The dried leaves of stevia are 30 times sweeter than sugar due to the presence of bioactive compounds which bring about its sweet taste (Geuns et al., 2003).

The origin of this species is South America. In the $19^{\text {th }}$ century, Moises Santiago Bertoni extracted and discovered the favourable effects of bioactive compounds (steviolglycosides) which are 300 times sweeter than sugar.

The steviol glycosides are known as natural sweeteners and they consist of several compounds such as: stevioside, steviol bioside, rebaudioside A, B, C, D, E, F and dulcosideA. Among them, the most important glycosides are stevioside and rebaudioside-A. The stevioside has a little bitter aftertaste whereas the rebaudioside-A determines the sweeter taste (Pal et al., 2014).
Today several food and drink processing firms use stevia in their products because of the thermal stability of its bioactive compounds. For instance, Kroyer (2010) reported that stevioside showed good stability up to $120^{\circ} \mathrm{C}$.

Firstly, Japan took the stevioside into market as a sweetener. Nowadays the largest production is located in China and $30 \%$ of their product is exported. Besides of China, there is successful production in the United States, Canada and Europe as well (Brandle et al., 1998; AmzadHossain et al., 2010).

Stevia is famous not only as a sweetener, but it is also known due to its several healing effects such as: anti-caries, lowers blood glucose level, calorie-free (Glycemic Index = 0 ), regulator of insulin level (Chatsudthipong-Muanprasat, 2009; Goyal et al., 2010; Lemus-Mondaca et al., 2012). For instance, Elnaga et al. (2016) have proved the slimming, blood sugar and cholesterol lowering effects in rat experiments. Furthermore, Khodjaeva et al. (2013) reported that the leaf extract of stevia has influences on hypertension and hyperglycemia. 
202

Stevia rebaudiana B. belongs to the Stevia genus (Asteraceae). The plant is about $40-60 \mathrm{~cm}$ high, but in its origin it can reach even $100 \mathrm{~cm}$ (Mishra et al., 2010). Stevia is a perennial species, however, in Europe it is grown as one year production. The stevia's feeder root is extensive and is located near to the soil surface. Besides, it is sensitive to excessive moisture which is the main reason why irrigation must be strictly monitored. The stem and the leaves are green and lightly covered with gland cell. The white tubular flowers are on the end of seed stalk. Regarding to the seeds $(2-3 \mathrm{~mm})$, their ability to germinate is extremely low, therefore, vegetative propagation is often applied which can assure the constant stevioside level in the progeny plants (Singh and Rao, 2005).

Stevia demands high temperature, the optimal is between 20 to $24^{\circ} \mathrm{C}$. It cannot resist temperature below $9{ }^{\circ} \mathrm{C}$, but in autumn it can tolerate even $0{ }^{\circ} \mathrm{C}$ (Singh and Rao, 2005).

For the temperature change it is rather sensitive, because its influence on stevioside synthesis. In India the development of stevia is good even on $30-40{ }^{\circ} \mathrm{C}$ (Chalapthi et al., 1997). According to Barathi (2003) and Takácsné Hajos et al. (2016), the optimum condition for stevia is when the temperature does not increase above $40{ }^{\circ} \mathrm{C}$ during the day and does not decrease below $10^{\circ} \mathrm{C}$ during the night. Besides, the length of sunlight hours and the intensity of sunshine have favourable effects on the vegetative improvement and on stevioside content (Valio-Rocha, 1966; Metivier-Viana, 1979; Zaidan et al., 1980; Viana, 1981; Mizukami et al., 1983).

The water need is medium; however, on temperate zone it should be irrigated. Drip irrigation is suggested with additional water supply $(25-30 \mathrm{~mm})$ occasionally. Therefore, high humidity can be avoided which is favourable for fungi diseases such as Septoria sp. and Sclerotinia sp. (Chang et al., 1997; Jain et al., 2014). During the vegetation it is necessary to ensure balanced water supply which can be carried out by mulching besides of protecting the plants against the weeds. Stevia has higher water needs after transplanting and cutting (Andolfi et al., 2002).

For the proper development of stevia, the soil needs to have $\mathrm{pH}$ between 5 to 7 , low salt content and high water capacity. The optimal NPK supply is $50: 25: 25 \mathrm{~kg}$ per hectare which is given 2-3 times during the vegetation (Rank-Midmore, 2006).

Positive correlation was observed between the amounts of bioactive compounds such as: stevioside, rebaudioside-A and the proper nutrient supply of the soil. For instance, Sheu and co-workers (1987) increased the stevioside and rebaudioside-A content by boron treatment $(5 \mathrm{ppm}$ concentration). Besides, Acuna et al. (1997) detected that Humiforte (synthetic amino acid, N, P, K and microelements) and Aminol (amino acid and N) combination is one of the most efficient methods to increase the stevioside content. Furthermore, proper potassium supply can increase resistance, yield (Ma and Shi, 2011) and stevioside content (with 5.08\%) in form of potassium-nitrate ( $\mathrm{Pal}$ et al., 2013).
On the other hand, shortness of calcium supply can cause decreased glycoside concentration (Filho et al., 1997).

During the first part of vegetation the growing of stevia is rather slow. In the middle of summer it can increase when the temperature is higher. During this period side-dressing the leaves and soil is recommended.

To increase the bunching of stevia, the $25-30 \mathrm{~cm}$ high plants should have the cutting at the $4^{\text {th }}$ double leaves; therefore, the side shoots will be increased. After cutting (first harvest) the proper water supply and side dressing is important for renewing the plantation. With this growing method 3-4 cuttings can be realized in a year (Takácsné Hájos et al., 2016). The cutting determines the renewing of the plant, therefore the depths should be taken care of.

The harvest method is mechanical with movable cutting machine which can collect the green biomass in one process. The yield depends on the growing area (number of cuttings), variety and soil conditions. For instance, in Canada $3000 \mathrm{~kg} \mathrm{ha}^{-1}$ leaf yield was measured by $105 \mathrm{mg} \mathrm{g}^{-1}$ stevioside concentration (Brandle-Rosa, 1992). Furthermore, in Paraguay the yield by unirrigated condition is $1500-2500 \mathrm{~kg} \mathrm{ha}^{-1}$, and $4300 \mathrm{~kg} \mathrm{ha}^{-1}$ by irrigation (Jordan Molero, 1984).

The fresh biomass needs to be spread and dried on aerated and protected area from direct sunshine immediately after cutting. The drying process is important to reduce the water content until $10-14 \%$. For artificial drying the optimal air temperature is $50-60{ }^{\circ} \mathrm{C}$. The binder drying machine is good for this process. After that, the dried leaves have to be removed from the stem. For storing, multilayer paper bags can be used to protect the leaves from humidity.

The aim of the experiment was to evaluate the effect of environmental friendly nutrition supply on the yield and bioactive compounds.

\section{Materials and Methods}

The experiment was carried out in the Horticultural Demonstration Garden of the Faculty of Agricultural and Food Science and Environmental Management, University of Debrecen in 2015. The transplanting was done on 28 of May, 2015 on raised bed where two rows have been prepared. The row distance was $33 \mathrm{~cm}$ and there was $25 \mathrm{~cm}$ between the plants. The experimental plots were mulched with composted food chips. For the treatment Dudarit (Table 1) and Sprintalga products were applied.

Dudarit was used for soil preparation $\left(150 \mathrm{~g} \mathrm{~m}^{-2}\right)$ and for side dressing with irrigation 5 times during the vegetation period ( 29 of July, 4 of August, 11 of August, 19 of August, 3 of Sept) in $0.04 \%$ concentration.

Sprintalga consist of peptides, alga extracts and amino acids. It can stimulate the root development and the intensity of mineral uptake (Biolchim Hungary Ltd.). For the treatment $0.04 \%$ solution was applied four times (30 of June, 14 of July, 4 of August, 11 of August) during the vegetation period with $200 \mathrm{~mL}$ per plant dose. The soil analysis before the treatment is presented in Table 2 .

The data of temperature during the vegetation period is shown in Fig. 1. 
Table 1. Content of Dudarit (Source: Duszén Ltd., 2016)

\begin{tabular}{cccc}
\hline Product content (\%) & Amount & Macronutrients (\%) & Amount \\
\hline Organic matter & 62 & $\mathrm{~N}$ & 0.05 \\
Minerals & 16 & $\mathrm{P}_{2} \mathrm{O}_{5}$ & 0.2 \\
Humic acids & 60 & $\mathrm{~K}_{2} \mathrm{O}$ & 0.3 \\
Moisture content & 22 & $\mathrm{Ca}$ & 3 \\
Micronutrients (\%) & & $\mathrm{Mg}$ & 0.5 \\
Fe, Mn, Zn, Cu, B, Mo & min. 0.5 & $\mathrm{~S}$ & 2.5 \\
\hline
\end{tabular}

Table 2. Soil analysis data (Debrecen, 2015)

\begin{tabular}{ccc}
\hline Analysed parameter (unit of measurement) & Amount \\
\hline $\mathrm{pH}(\mathrm{KCL})$ & 7.10 \\
Plasticity index of Arany $\mathrm{K}_{\mathrm{A}}$ & 41.50 \\
Total water soluble salto $(\mathrm{w} / \mathrm{w})$ & 0.04 \\
$\mathrm{CaCO}_{3} \%(\mathrm{w} / \mathrm{w})$ & 0.84 \\
$\mathrm{Humus} \%(\mathrm{w} / \mathrm{w})$ & 2.87 \\
$\mathrm{AL}-$ soluble $\mathrm{P}_{2} \mathrm{O}_{5}\left(\mathrm{mg} \mathrm{kg}^{-1}\right)$ & 439.10 \\
$\mathrm{AL}-\mathrm{soluble}_{2} \mathrm{O}\left(\mathrm{mg} \mathrm{kg}^{-1}\right)$ & 227.50 \\
\hline $\mathrm{KCL}-$ soluble $\mathrm{NO}_{3}^{-}+\mathrm{NO}_{2}^{-}$- Nitrogen $\left(\mathrm{mg} \mathrm{kg}^{-1}\right)$ & 3.37 \\
\hline
\end{tabular}

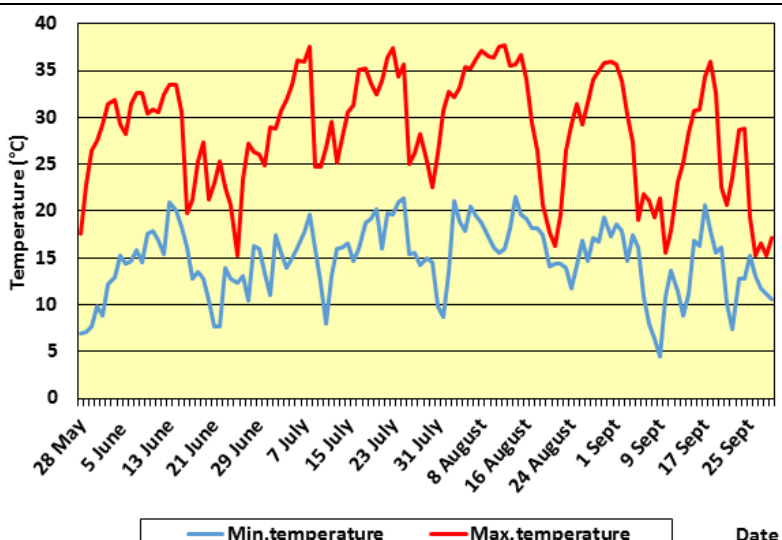

Fig. 1. Mean temperature values during the vegetation period (Debrecen, 2015)

In the experimental year, the natural precipitation was not sufficient $(200 \mathrm{~mm})$ during the growing period; therefore, the plantation was irrigated regularly two times a week with $30 \mathrm{~mm}$ water.

\section{Measurements on open field}

- plant height (cm) - June 4, 12, 22, 30; July 6, 22; August 13; Sept 7, 29

- relative chlorophyll content (SPAD) - with Minolta SPAD-502; 50 measurements on every control and treated plots (Dobos, 2013) - June 4, 22; July 6, 22; Sept 7,29

- leaf area index (LAI) - with portable SunScan Canopy Analysis Systems (Karancsi et al., 2014) June 22; July 6, 22; Sept 7, 29

- row weight ( $\mathrm{g} \mathrm{m}^{-2}$ and g per plant)

- dry weight ( $\mathrm{g} \mathrm{m}^{-2}$ and g per plant)

- leaf and stem ratio by different cutting times

\section{Analytical measurements}

- $\quad$ stevioside (g per $100 \mathrm{~g}$ dry weight)

- rebaudioside- $A$ (g per $100 \mathrm{~g}$ dry weight) with HPLC method (Kolb et al., 2001)

\section{Results and Discussion}

\section{Plant height}

The evaluation of plant height depends on control and treated plots and the time of pinching and cutting (Fig. 2).

Slow development was detected until the $4^{\text {th }}$ measurement. After the pruning (between the $4^{\text {th }}$ and $5^{\text {th }}$ measurement) the side shoot development was increased. The pruning followed by increased temperature caused favourable effect on plant height. Thereby, it seems that the warm condition improved the regeneration of the plants after cutting.

The favourable effect of treatment on plant height was proved not only after pinching, but also at the final period of vegetation. Similar effect was observed on fresh biomass production (Fig. 3).

The treatment was efficient on the stevia plants, which can be explained by the improved root system and better ability of water and mineral uptake.

The marketable product of stevia is the dried leaf. Therefore, it is important to follow the leaf and stem ratio which is higher at the first cutting (Fig. 4).

The $1^{\text {st }}$ cutting showed higher leaf stem ratio against the $2^{\text {nd }}$ cutting. Between the treated and control plots no statistical differences were found.

Favourable effect of treatment was determined on the leaf weight per plant during the second cutting. The leaf yield was higher ( $10.23 \mathrm{~g}$ per plant) on the treated plots than on the control ones (6.33 g per plant) which is statistically significant.

\section{SPAD measurements}

The relative chlorophyll content of leaves was evaluated during the vegetation. The treated plants have showed higher SPAD values (30.08-41.63), however these values were not statistically significant (Fig. 5). Furthermore, great differences were found among the different measurement times. Lower values were detected at the end of the growing period which can be explained by elder leaves. 


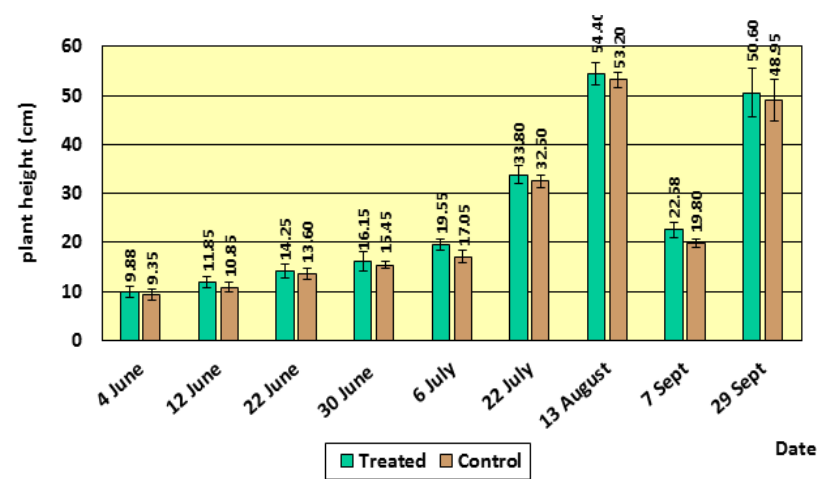

Fig. 2. The plant height $(\mathrm{cm})$ of treated and control plots (Debrecen, 2015)

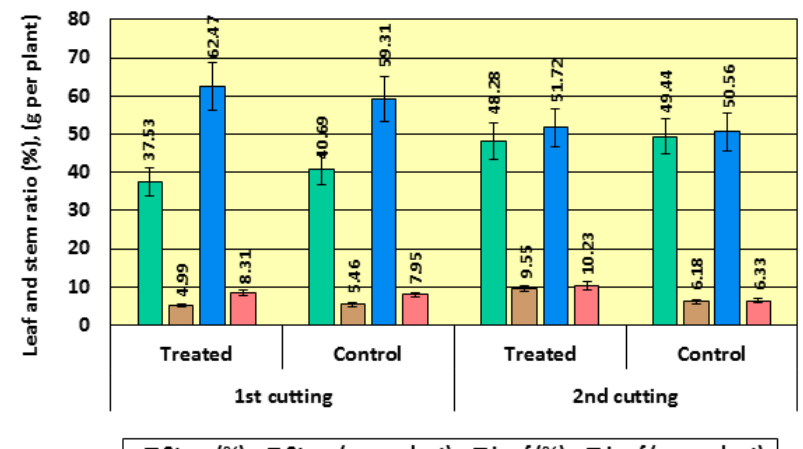

Fig. 4. Leaf and stem ratio during the cuttings (Debrecen, 2015)

\section{LAI measurements}

Previously, positive correlation was observed between the weight of biomass and the leaf area. Thus, it was measured (leaf area $\mathrm{m}^{-2}$ ) in the experiment (Fig. 6).

The increasing effect was detected till the cutting time. The highest LAI value $\left(2.23-2.39 \mathrm{~m}^{2}\right.$ per $\left.\mathrm{m}^{2}\right)$ was measured before the second cutting.

\section{Correlation by Pearson}

The results of correlation analysis by Pearson are shown in Table 3.

The correlation between the treatment and plant height $(\mathrm{r}=0.508)$ was proved only by the second cutting. It can be explained by the favourable effect of Dudarit and Sprintalga which was expressed rather at the end of the growing period. Similar tendency was detected between the treatment and the biomass production, where the value for the first cutting was $r=0.635$ and for second cutting $r=0.931$.

The correlation between plant height and SPAD was medium strong negative $(r=-0.509)$ at first cutting, while between the plant height and the biomass this value was $r=$ 0.477 .

\section{Bioactive compounds}

Stevioside and rebaudioside-A content were measured as the most important bioactive compounds of stevia (Fig. 7). Statistical differences were not found between the control and treated plots.

Stevioside concentration was measured between 161.5$168.7 \mathrm{mg} \mathrm{g}^{-1}$ on treated and control plots. These values are

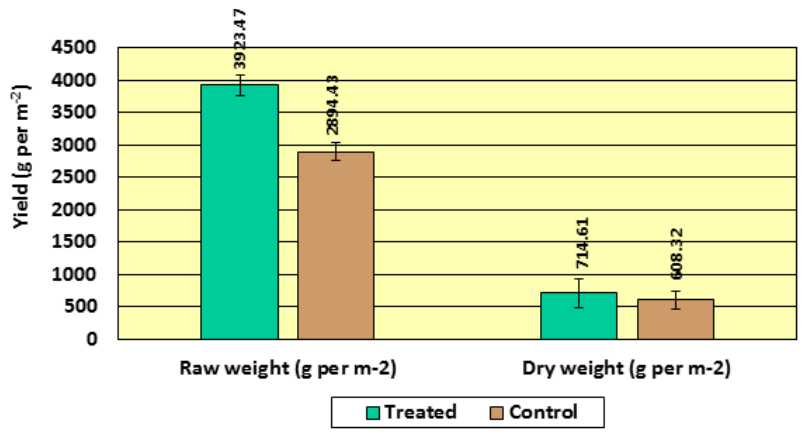

Fig. 3. Yield of raw and dry weight $\left(\mathrm{g} \mathrm{m}^{-2}\right)$ (Debrecen, 2015)

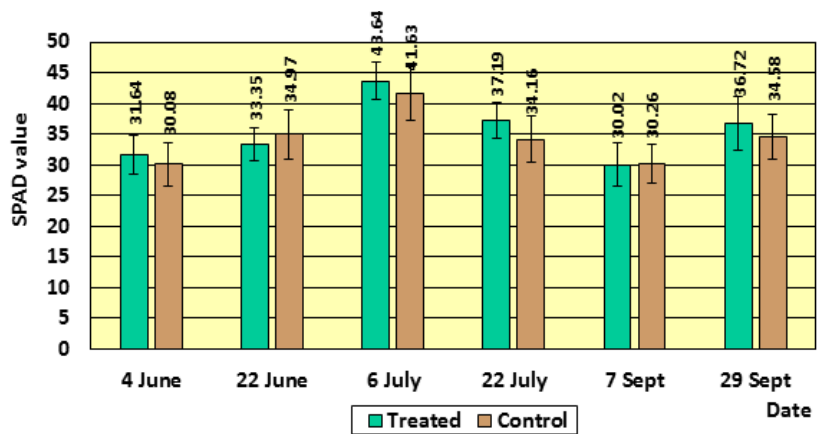

Fig. 5. The SPAD values during the vegetation (Debrecen, 2015)

higher than the ones detected by Brandle-Rosa (1992) in Canada (105 $\mathrm{mg} \mathrm{g}^{-1}$ ). Vafadar et al. (2014) and GautamKafle (2011) measured much lower amounts on non-field experiments, $48.05 \mathrm{mg} \mathrm{g}^{-1}$ and $57-76 \mathrm{mg} \mathrm{g}^{-1}$ respectively. The rebaudioside-A content was between $11.7-13.3 \mathrm{mg} \mathrm{g}^{-1}$ which is similar to the amount measured by Gautam-Kafle (2011); 17-21 $\mathrm{mg} \mathrm{g}^{-1}$ respectively. The lower amount can be explained with the negative correlation between stevioside and rebaudioside-A due to their biosynthetic relationship (Shibata et al., 1991).

The experiment proves that the Hungarian climatic condition is favourable for stevia production with good inner quality due to the influence of daily solar radiation during the summer period.

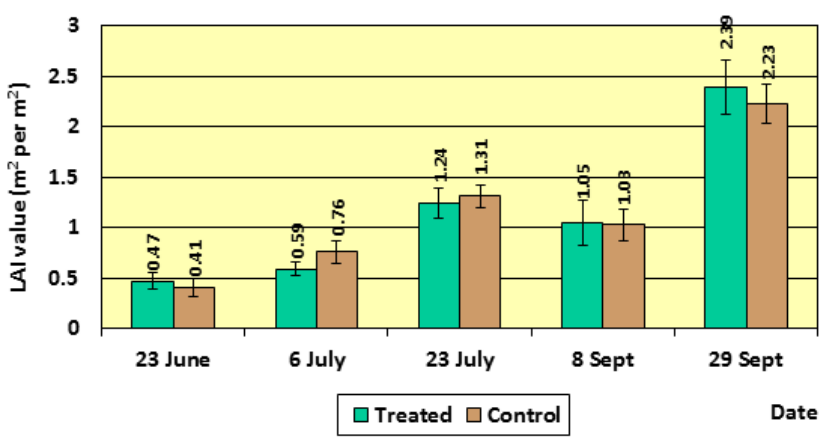

Fig. 6. LAI values during the vegetation period (Debrecen, 2015) 
Table 3. Correlation between the parameters by Pearson (Debrecen, 2015)

\begin{tabular}{ccccccccc}
\hline & \multicolumn{9}{c}{ 1st cutting } & \multicolumn{3}{c}{ 2nd cutting } \\
\cline { 2 - 8 } & Plant height & Biomass & LAI & SPAD & Plant height & Biomass & LAI & SPAD \\
\hline Treatment & -0.139 & $0.635\left(^{* *}\right)$ & -0.090 & 0.289 & $0.508\left(^{*}\right)$ & $0.931\left(^{* *}\right)$ & -0.055 & 0.309 \\
Plant height & - & 0.326 & -0.140 & $-0.509\left(^{*}\right)$ & - & $0.477\left(^{*}\right)$ & 0.074 & 0.217 \\
Biomass & - & - & -0.214 & -0.054 & - & - & -0.163 & 0.221 \\
LAI & - & - & - & -0.063 & - & - & - & 0.350 \\
\hline
\end{tabular}

${ }^{*}$ The correlation is valid with $95 \%$ confidence. ${ }^{* *}$ The result can be used with $99 \%$ confidence. Where is no sign $\left({ }^{*}\right)$ there is no statistically significant difference between the values.

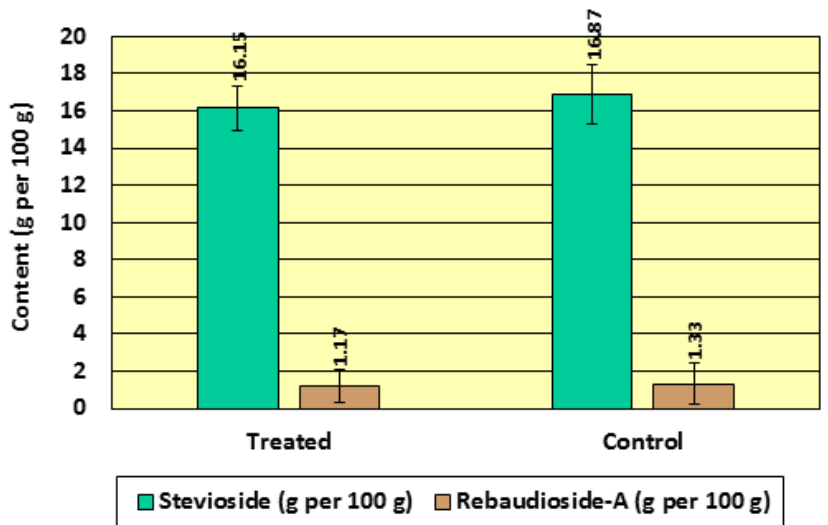

Fig. 7. Stevioside and rebaudioside- $A$ content (g per $100 \mathrm{~g}$ dry weight) (Debrecen, 2015)

\section{Conclusions}

Our results proved that stevia production can be successful in Hungary propagated by transplants at the end of May. With the two cuttings the total biomass was about $4 \mathrm{~kg} \mathrm{~m}^{-2}$ which is more than $700 \mathrm{~g}$ dried material. The bioactive compounds of the dried material are the following: stevioside (161.5 $\mathrm{mg} \mathrm{g}^{-1}$ ) and rebaudioside-A $\left(11.7 \mathrm{mg} \mathrm{g}^{-1}\right.$ ) which were measured on treated plots. The Dudarit and Sprintalga treatment could not show statistically favourable effect on these parameters to control plots.

In our experiment, the environmentally friendly fertilisers produced good effect on leaf yield (10.23 g per plant) comparing to control (6.33 g per plant) by second cutting.

\section{References}

Acuna I, Nepovim A, Valicek P (1997). Micro propagation of plants Stevia rebaudiana in vitro and content of stevioside in leaves after application of growth regulators under field conditions. Agricultura Tropica et Subtropica 30:51-60.

Amzad-Hossain M, Siddique A, Mizanur-Rahman S, Amzad-Hossain M (2010). Application of Stevia and research and development data.Japan: I.S.U.Asian Journal of Traditional Medicines 5:56-61.

Andolfi L, Ceccarini L, Macchia M (2002). Bio-agronomic characteristics of Stevia rebaudiana. Informatore Agrario 58:48-51.

Barathi N (2003). Stevia - The calorie free natural sweetener. Natural Product Radiance 2:120-122.
Brandle JE, Rosa N (1992). Heritability for yield, leaf, stem ratio and stevioside content estimated from a landrace cultivar of Stevia rebaudiana. Canadian Journal of Plant Science 72:1263-1266.

BrandleJE, Starratt AN, Gijzen M (1998). Stevia rebaudiana: Its agricultural, biological, and chemical properties. Canadian Journal of Plant Science 78:527-536.

Chalapathi MV, Thimmegowda S, Rama Krishna Prama VR, Prasad TG (1997). Natural non-calorie sweetener stevia (Stevia rebaudiana Bertoni). A future crop of India. Crop Research-HISAR 14:347-350.

Chang KF, Howard RJ, Gaudiel RG (1997). First report on Stevia as a host for Sclerotiniasclerotiorum. Plant Disease 81(3):311.

Chatsudthipong V, Muanprasat C (2009). Stevioside and related compounds. Therapeutic benefits beyond sweetness. Pharmacology and Therapeutics 121(1):41-54.

Dobos ACS (2013). Precíziós növénytermesztés [Precision farming]. Debreceni Egyetem. Agrár- és Gazdálkodástudományok Centruma, Debrecen, pp 67.

Elnaga NIEA, Massoud MI, Yousef MI, Mohamed HHA (2016). Effect of stevia sweetener consumption as non-caloric sweetening on body weight gain and biochemical's parameters in overweight female rats. Annals of Agricultural Science 61(1):155-163.

Filho LOF, Malavolta E, Filho OFDL (1997). Symptoms of nutritional disorders in stevia (Stevia rebaudiana). Scientia Agricola 54:53-61.

Gautam Kafle G (2011). Some studies on the physiology of Stevia rebaudiana (Bertoni). Thesis, CQUniversity Australia, Rockhampton.

Geuns JMC, Augustijns P, Mols R, Buyse JG, Driessen B (2003). Metabolism of stevioside in pigs and intestinal absorption characteristics of stevioside, rebaudioside A and steviol. Food and Chemical Toxicology 41(11):1599-1607.

Goyal SK, Samsher, Goyal RK (2010). Stevia (Stevia rebaudiana) a biosweetener: A review. International Journal of Food Sciences and Nutrition 61(1):1-10.

Jain P, Kachhwaha S, Kothari SL (2014). Biotechnology and metabolic engineering of Stevia rebaudiana (Bert.) Bertoni: perspective and possibilities. International Journal of Life Sciences Biotechnology and Pharma Research3(3):15-37.

Jordan Molero F (1984). La propagacion de ka’a he'e, Stevia rebaudiana Bertoni [The propagation of Stevia rebaudiana Bertoni]. PrimerSimposio Nacional de la stevia (kaa hee) Julio, Asunción, Paraguay, pp 29.

Karancsi LG, Novák A, Vári E (2014). Müszeres mérések a Növénytermesztési és Tajöökológiai tanszéken [Analytical measurements at the department of plant production and landscape ecology]. 
Debreceni Egyetem Mezőgazdaság-, Élelmiszertudományi és Környezetgazdálkodási Kar, Kari Napló. 2014. januári szám, pp 20-26.

Khodjaeva U, Bojnanska T, Vietoris V, Sytar O (2013). About food additives as important part of functional food. Journal of Microbiology, Biotechnology and Food Sciences 2 (Special issue 1) 2125-2135.

Kolb N, Herrera JL, Ferreyra DJ, Uliana RF (2001). Analysis of sweet diterpene gycosides from Stevia rebaudiana: Improved HPLC method. Journal of Agricultural and Food Chemistry 49(10):4538-4541.

Kroyer G (2010). Stevioside and Stevia-sweetener in food: application, stability and interaction with food ingredients. Journal für Verbraucherschutz und Lebensmittelsicherheit 5(2):225-229.

Lemus-Mondaca R, Vega-Gálvez A, Zura-Bravo L, Ah-Hen K (2012). Stevia rebaudiana Bertoni, source of a high-potency natural sweetener: A comprehensive review on the biochemical, nutritional and functional aspects. Food Chemistry 132(3):1121-1132

Ma L, Shi Y (2011). Effects of potassium fertilizer on physiological and biochemical index of Stevia rebaudiana Bertoni. Energy Procedia 5:581586.

Metivier J, Viana AM (1979). The effect of long and short day length upon the growth of whole plants and the level of soluble proteins, sugars and stevioside in leaves of Stevia rebaudiana. Journal of Experimental Botany 30:1211-1222

Mishra PK, Singh R, Kumar U, Prakash V (2010). Stevia rebaudiana - A magical sweetener. Global Journal of Biotechnology and Biochemistry 5(1):62-74

Mizukami H, Shiba K, Ohashi H (1983). Effect of temperature on growth and stevioside formation of Stevia rebaudiana. Shoyakugaku Zasshi 37:175-179.

Pal PK, Mahajan M, Prasad R, Pathania V, Singh B, Ahuja PS (2014). Harvesting regimes to optimize yield and quality in annual and perennial Stevia rebaudiana under sub-temperate conditions. Industrial Crops and Products 65:556-564.
Pal PK, Prasad R, Pathania V (2013). Effect of decapitation and nutrient applications on shoot branching, yield, and accumulation of secondary metabolites in leaves of Stevia rebaudiana Bertoni. Journal of Plant Physiology 170(17):1526-1535.

Rank AH, Midmore DJ (2006). Stevia, an intense, natural sweetener. Australian Government: Rural Industries Research and Development Corporation.

Sheu BW, Tamai F, Motoda Y (1987). Effects of boron on the growth, yield and contents of stevioside and rebaudioside A of Stevia rebaudiana. Journal of Agricultural Science. Tokio Nogyo Daigaku 31:265-272.

Shibata H, Sonoke S, Ochiai H, Nishihashi H, Yamada M (1991). Glucosylation of steviol and steviol glucosides in extracts from Stevia rebaudiana Bertoni. Plant Physiology 95(1):152-156.

Singh SD, Rao GP (2005). Stevia: the herbal sugar of 21st century. Sugar Tech 7(1):17-24.

Takácsné Hájos M, Rubóczki T, Kiss A (2016). Possibility of stevia (Stevia rebaudiana B.) production in Hungary. International Journal of Horticultural Science 22(1-2):29-32.

Vafadar F, Amooaghaie R, Otroshy M (2014). Effects of plant-growthpromoting rhizobacteria and arbuscular mycorrhizal fungus on plant growth, stevioside, NPK, and chlorophyll content of Stevia rebaudiana. Journal of Plant Interactions 9(1):128-136.

Valio IFM, Rocha RF (1966). Effect of photoperiod and growth regulators on growth and flowering of Stevia rebaudiana Bertoni. Japanese Journal ofCropScience 46(2):243-248.

Viana AM (1981). Analysis of Stevia rebaudiana Bert. for stevioside during photoperiod of 16 and 18 hours. First Brazilian seminar on Stevia rebaudiana, Brazil, pp 25-26.

Zaidan LBP, Dietrich SMC, Felippe GM (1980). Effect of photoperiod on flowering and stevioside content in plants of Stevia rebaudiana Bertoni. Japanese Journal ofCropScience 49(4):569-574. 